\title{
Association of single nucleotide polymorphisms in Pre-miR-27a, Pre-miR- 196a2, Pre-miR-423, miR-608 and Pre-miR- 618 with breast cancer susceptibility in a South American population
}

Sebastián Morales ${ }^{1,2}$, Felipe Gulppi ${ }^{3}$, Patricio Gonzalez-Hormazabal' ${ }^{1}$, Ricardo Fernandez-Ramires ${ }^{4}$, Teresa Bravo $^{5}$, José Miguel Reyes ${ }^{6}$, Fernando Gomez ${ }^{7}$, Enrique Waugh ${ }^{7}$ and Lilian Jara ${ }^{1,8^{*}}$

\begin{abstract}
Background: MicroRNAs (miRNAs) are a novel class of endogenous, non-coding, single-stranded RNAs capable of regulating gene expression by suppressing translation or degrading mRNAs. Single nucleotide polymorphisms (SNP) can alter miRNA expression, resulting in diverse functional consequences. Previous studies have examined the association of miRNA SNPs with breast cancer (BC) susceptibility. The contribution of miRNA gene variants to BC susceptibility in South American women had been unexplored. Our study evaluated the association of the SNPs rs895819 in pre-miR27a, rs11614913 in pre-miR-196a2, rs6505162 in pre-miR-423, rs4919510 in miR-608, and rs2682818 in pre-mir-618 with familial BC and early-onset non-familial BC in non-carriers of BRCA1/2 mutations from a South American population.

Results: We evaluated the association of five SNPs with BC risk in 440 cases and 807 controls. Our data do not support an association of rs11614913:C > T and rs4919510:C > G with BC risk. The rs6505162:C > A was significantly associated with increased risk of familial $\mathrm{BC}$ in persons with a strong family history of $\mathrm{BC}(\mathrm{OR}=1.7[95 \% \mathrm{Cl} 1.0-2.0]$ $p=0.05)$. The rs 2682818:C $>A$ genotype $C / A$ is associated with an increased $B C$ risk in non-familial early-onset $B C$ For the rs895819:A > G polymorphism, the genotype $G / G$ is significantly associated with reduced $B C$ risk in families with a moderate history of $\mathrm{BC}(\mathrm{OR}=0.3[95 \% \mathrm{Cl} 0.1-0.8] p=0.01)$.

Conclusions: The contribution of variant miRNA genes to BC in South American women had been unexplored. Our findings support the following conclusions: a) rs6505162:C > A in pre-miR-423 increases risk of familial BC in families with a strong history of $B C ;$ b) the C/A genotype at rs2682818:C > A (pre-miR-618) increases BC risk in non-familial early-onset BC; and C) the G/G genotype at rs895819:A > G (miR-27a) reduces BC risk in families with a moderate history of $B C$.
\end{abstract}

Keywords: Familial breast cancer, Polymorphisms, MicroRNA, South American population

\footnotetext{
* Correspondence: ljara@med.uchile.cl

${ }^{1}$ Human Genetics Program, Institute of Biomedical Sciences (ICBM), School of Medicine, University of Chile, Av. Independencia 1027, Santiago, Chile

${ }^{8}$ Laboratorio de Genética Molecular Humana, Facultad de Medicina, Instituto de Ciencias Biomédicas (ICBM), Programa de Genética, Universidad de Chile, Independencia 1027, Santiago, Chile

Full list of author information is available at the end of the article
} 


\section{Background}

Breast cancer $(\mathrm{BC})$ is the most common cancer among women worldwide. In Chile, BC has the highest mortality rate among cancers (15.8/100,000 women), and its incidence has increased in all age groups analyzed [1]. Genetics factors play an important role in BC development. Currently, there is consensus that mutations in genes BRCA 1 and BRCA 2 are responsible for an average $16 \%$ of the risk for familial BC [2]. It has been proposed that other susceptibility alleles, called moderate or low penetrance, could be responsible for a significant percentage of $\mathrm{BC}$ susceptibility. To date, our group has studied the contribution of moderate and low penetrance genes (PALB2 [3], BARD1 [4], ATM [5], CHEK 2 [6], RAD51 [7], FGFR2 [8], MAP3K [8], TOX 3 [9], 8q24. [9] and 2q35 [9]) to genetic susceptibility for familial BC. Nevertheless, a large part of the genetic component of familial cases remains unidentified [10]. Research on known genes continues in order to further understand $\mathrm{BC}$ development, with an emerging interest in epigenetics and gene regulation. One of the most surprising advances in understanding the mechanisms of gene regulation has been the discovery of microRNA (miRNA) [11]. miRNAs are single-stranded RNAs of $~ 22$ nucleotides that can regulate gene expression by either degrading or blocking translation of target miRNA, mainly by binding to their 3'-UTR $[12,13]$. MiRNAs are specific to different mRNAs, and approximately $30 \%$ of all human genes are regulated by miRNA $[14,15]$. The discovery of miRNAs has been followed by findings highlighting their important and diverse roles in many molecular pathways and biological processes, including development, apoptosis, differentiation, and cell proliferation $[16,17]$, as well as their implication in various human diseases including cancer. Growing evidence indicates that miRNAs can work as oncogenes or tumor suppressors, depending on which gene(s) they modulate [18]. Atypical expression of various miRNAs has been observed in the development and progression of numerous human cancers [19-21]. Single nucleotide polymorphisms (SNPs) are the most common type of variation in the human genome. SNPs present in the miRNA gene regions can alter expression, lead to maturation to aberrant miRNA, and affect target binding affinity and specificity [22]. Many epidemiological studies have examined the association of miRNA SNPs with cancer susceptibility [19]. In $\mathrm{BC}$, several case-control studies and meta-analyses have evaluated associations between miRNA gene polymorphisms and BC risk in European [23-28], Asian [29, 30], Arab [31], and Jewish [32] populations. With the exception of one study in a Brazilian population [33], the contribution of variant miRNA genes to $\mathrm{BC}$ in South American women had been unexplored. In this study, we selected specific SNPs in five miR and evaluated the effects of these SNPs on miR expression and biological function. Recent studies have demonstrated that miR-27a exhibits oncogenic activity by regulating specific transcription factors and the $G 2-M$ checkpoint [34-36]. The rs895819:A > G is located at position 40 relative to the first nucleotide of pre-miR-27a [37], and it has been hypothesized that rs895819 could have an effect on the secondary structure of pre-miR-27a, which subsequently affects the processing and/or maturation of miR-27a. Zhang et al. [38] showed that miR-27a expression was significantly lower in $\mathrm{BC}$ samples with $\mathrm{A} / \mathrm{G}$ or G/G genotypes as compared to samples with A/A genotypes, indicating that the A-to-G change decreases expression mature miR-27a. The variant rs11614913, located in the mature miR-196a-3p sequence, could lead to less efficient processing of the miRNA precursor to its mature form and diminish its capacity to regulate target genes such as $H O X B 2$, HOXB3, HOXC3, HOXB5, GADD45G, INHBB, and TP63 [39]. Several studies have shown that miR-423 plays an important role in tumorigenesis [40-42]. In hepatocellular carcinoma, miR-423 promotes cell growth and regulates G(1)/S transition by targeting p21 Cip1/waf1 [40]. Zhao et al. [43], demonstrated that the SNP rs6505162 in pre-miR423 affects mature miR expression, and miR-423 plays a potentially oncogenic role in breast tumorigenesis. A few polymorphisms are located in the mature microRNA sequence. Such polymorphisms could directly affect the binding of microRNAs to hundreds of target mRNAs. One of these is rs4919510:C > G, located in mature miR-608. The predicted targets of miR-608 include interleukin-1 alpha (IL1A), growth hormone receptor (GHR), and TP53 [44]. These genes have been reported to be associated with $\mathrm{BC}$ [45-47]. A study by Huang et al. [48] showed that the polymorphism rs4919510:C $>\mathrm{G}$ in the mature miR-608 sequence contributes to the risk of HER2+ BC. Deregulation of miR-618 has previously been linked to a number of malignancies, including hepatocellular carcinoma [49], male BC [50], and Barrett's esophageal cancer [51]. Because SNP rs2682818 is part of the miR-618 precursor's stem-loop sequence, it can affect miR-618 levels. The SNP may alter the secondary stem-loop structure, which in turn influences how pre-miR-618 is processed into its mature form. [52]. $\mathrm{Fu}$ et al. [52] suggest that the presence of the variant A allele may negatively impact the production of mature miR618 by interfering with the post-transcriptional miRNA biogenic process. Considering the proceeding information, in this study we evaluated the association of rs895819 in pre-miR27a, rs11614913 in pre-miR-196a2, rs6505162 in pre-miR-423, rs4919510 in miR-608, and rs2682818 in pre-mir-618 with familial BC and early-onset non-familial $\mathrm{BC}$ in non-carriers of $B R C A 1 / 2$ mutations from a South American population.

\section{Methods}

\section{Families}

A total of $440 \mathrm{BC}$ cases (one case per family) belonging to 440 high-risk $B R C A 1 / 2$-negative Chilean families 
were selected from the files of the Servicio de Salud del Area Metropolitana de Santiago, Corporación Nacional del Cáncer (CONAC), and other private services in the Metropolitan Area of Santiago. The majority of the cases are from the Metropolitan Region, and all controls are from the Metropolitan Region. All index cases were tested for $B R C A 1$ and $B R C A 2$ mutations as previously described [53]. Pedigrees were constructed on the basis of an index case considered to have the highest probability of being a deleterious mutation carrier. None of the families met the strict criteria for other known syndromes involving $\mathrm{BC}$, such as Li-Fraumeni, ataxiatelangiectasia, or Cowden disease.

Table 1 shows the specific characteristics of the families selected according to the inclusion criteria. All families participating in the study were of self-reported Chilean ancestry dating from several generations, confirmed with extensive interviews with several members of each family from different generations. In the selected families; $16 \%$ (70/440) had cases of bilateral BC; $9 \%$ (40/440) had cases of both $\mathrm{BC}$ and ovarian cancer (OC); and $1.1 \%(5 / 440)$ had male $\mathrm{BC}$. In the $\mathrm{BC}$ group, the mean age at diagnosis was 42.1 years, and $75.2 \%$ had age of onset $<50$ years.

This study was approved by the Institutional Review Board of the School of Medicine of the University of Chile. Informed consent was obtained from all of the participants.

\section{Control population}

The sample of healthy Chilean controls $(n=807)$ was recruited from CONAC files. DNA samples were taken from unrelated individuals with no personal or family history of cancer who consented to anonymous testing. These individuals were interviewed and informed as to the aims of the study. DNA samples were obtained in accordance with all ethical and legal requirements. The control sample was matched by age and socioeconomic strata with respect to the cases.

\section{Genotyping analysis}

Genomic DNA was extracted from peripheral blood lymphocytes of 440 cases belonging to the selected high-risk

Table 1 Inclusion criteria for the families studied

\begin{tabular}{ll}
\hline Inclusion criteria & Families: $\mathrm{n}(\%)$ \\
\hline $\begin{array}{l}\text { Three or more family members with breast and/or } \\
\text { ovarian cancer }\end{array}$ & $121(27.5 \%)$ \\
Two family members with breast and/or ovarian & $148(33.6 \%)$ \\
cancer & \\
Single affected individual with breast cancer $\leq$ age 35 & $87(19.8 \%)$ \\
Single affected individual with breast cancer between & $84(19.1 \%)$ \\
36 and 50 years of age & \\
TOTAL & $440(100 \%)$ \\
\hline
\end{tabular}

families and 807 controls. Samples were obtained according to the method described by Chomczynski [54].

Genotyping of the SNPs rs11614913:C > T, rs6505162:C > A, rs895819:A > G, rs2682818:C > A, and rs4919510:C > G was performed using the commercially-available TaqMan Genotyping Assay (Applied Biosystems, Foster City, CA) (assay IDs C_31185852_10, C_11613678_10, C_305 6952_20, C_286717_10, and C_2826025_10, respectively). The reaction was performed in a $10-\mathrm{uL}$ final volume containing 5 ng of genomic DNA, 1X TaqMan Genotyping Master Mix, and 1X TaqMan SNP Genotyping Assay. The polymerase chain reaction was carried out in a StepOnePlus Real-Time PCR System (Applied Biosystems, Foster City, CA). The thermal cycles were initiated for $10 \mathrm{~min}$ at $95^{\circ} \mathrm{C}$, followed by 40 cycles each of $92^{\circ} \mathrm{C}$ for $15 \mathrm{~s}$ and $60^{\circ}$ $\mathrm{C}$ for $1 \mathrm{~min}$. Each genotyping run contained DNA controls confirmed by sequencing. The alleles were assigned using the StepOne software V2.2 (Applied Biosystems, Foster City, CA). As a quality control, we repeated the genotyping on $\sim 10 \%$ of the samples, and all genotype scoring was performed and checked separately by two reviewers unaware of case-control status.

\section{Statistical analysis}

The Hardy-Weinberg equilibrium assumption was assessed in the control sample using a goodness-of-fit chi-square test (HW Chisq function included in the "HardyWeinberg”.package v.1.4.1). Fisher's exact test was used to test the association between genotypes and/or alleles for cases and controls. $p<0.05$ was used as the criterion of significance. Odds ratios (OR) and $95 \%$ confidence intervals (CI) were calculated to estimate the strength of the associations in cases and controls (odds ratio fisher function included in the EpiTools package v.0.5-6).

\section{Results}

Selected characteristics of the 440 BRCA1/2-negative cases are summarized in Table 1 . For the analysis, the whole case sample was subdivided into two groups: cases with two or more family members with $\mathrm{BC}$ and/or OC $(n=269)$ (subgroup A) and non-familial early-onset $\mathrm{BC}(\mathrm{B} \leq 50$ years) $(n=171)$ (subgroup $\mathrm{B})$. The genotype distributions and allele frequencies of the pre-miR-27a rs895819:A > G, pre-miR-196a rs11614913:C > T, premiR-423 rs6505162:C > A, miR-608 rs4919510:C > G, and pre-miR-618 rs2682818:C > A polymorphisms in the whole data set and in subgroups A and B with respect to the controls are shown in Table 2. The observed genotype frequencies for four of the five polymorphisms were in Hardy-Weinberg equilibrium in controls $(p=0.12$ for rs11614913:C > T, $p=0.7$ for rs6505162:C > A, $p=0.3$ for rs4919510:C $>\mathrm{G}$, and $p=0.8$ for $\mathrm{rs} 2682818: \mathrm{C}>\mathrm{A}$, respectively), while for rs895819:A > G the $p$-value was 0.02 . 
Table 2 Genotype and allele frequencies of rs895819, rs11614913, rs6505162, rs4919510 and rs2682818 in BRCA1/2-negative breast cancer cases and controls

\begin{tabular}{|c|c|c|c|c|c|c|c|c|c|c|}
\hline \multirow[b]{2}{*}{$\begin{array}{l}\text { Genotype or } \\
\text { allele }\end{array}$} & \multirow[b]{2}{*}{$\begin{array}{l}\text { Controls (\%) } \\
(n=807)\end{array}$} & \multicolumn{3}{|c|}{ All BC cases $(n=440)$} & \multicolumn{3}{|c|}{$\begin{array}{l}\text { Families with } \geq 2 \text { BC and/or } \\
\text { OC cases }(n=269)\end{array}$} & \multicolumn{3}{|c|}{$\begin{array}{l}\text { Families with a single case, } \\
\text { diagnosed at } \leq 50 \text { years of } \\
\text { age }(n=171)\end{array}$} \\
\hline & & BC cases (\%) & $p$-value ${ }^{a}$ & OR $[95 \% \mathrm{Cl}]$ & BC cases (\%) & $p$-value ${ }^{a}$ & OR $[95 \% \mathrm{Cl}]$ & BC cases (\%) & $p$-value ${ }^{a}$ & OR $[95 \% \mathrm{Cl}]$ \\
\hline \multicolumn{11}{|c|}{ rs895819 (Pre-miR 27a) } \\
\hline $\mathrm{A} / \mathrm{A}$ & $432(53 \%)$ & $245(56 \%)$ & - & 1.0 (ref) & $146(54 \%)$ & - & 1.0 (ref) & $99(58 \%)$ & - & 1.0 (ref) \\
\hline $\mathrm{A} / \mathrm{G}$ & $298(37 \%)$ & $166(38 \%)$ & 0.9 & $0.9[0.7-1.2]$ & $105(39 \%)$ & 0.8 & $1.0[0.7-1.3]$ & $61(36 \%)$ & 0.5 & $0.8[0.6-1.2]$ \\
\hline $\mathrm{G} / \mathrm{G}$ & 77 (10 \%) & $29(6 \%)$ & 0.08 & $0.6[0.4-1.0]$ & 18 (7 \%) & 0.1 & $0.6[0.4-1.1]$ & $11(6 \%)$ & 0.1 & $0.6[0.3-1.2]$ \\
\hline $\mathrm{A} / \mathrm{G}+\mathrm{G} / \mathrm{G}$ & $375(47 \%)$ & 195 (44 \%) & 0.4 & $0.9[0.7-1.1]$ & $123(46 \%)$ & 0.8 & $0.9[0.7-1.2]$ & $72(42 \%)$ & 0.3 & $0.8[0.6-1.1]$ \\
\hline Allele A & $1162(0.72)$ & $656(0.75)$ & - & 1.0 (ref) & $397(0.74)$ & - & 1.0 (ref) & $259(0.76)$ & - & 1.0 (ref) \\
\hline Allele G & $452(0.28)$ & $224(0.25)$ & 0.1 & $0.8[0.7-1.0]$ & $141(0.26)$ & 0.4 & $0.9[0.7-1.1]$ & $83(0.24)$ & 0.1 & $0.8[0.6-1.0]$ \\
\hline \multicolumn{11}{|c|}{ rs11614913 (Pre-miR 196a2) } \\
\hline$C / C$ & $342(42 \%)$ & $192(44 \%)$ & - & 1.0 (ref) & $113(42 \%)$ & - & 1.0 (ref) & 79 (46 \%) & - & 1.0 (ref) \\
\hline $\mathrm{C} / \mathrm{T}$ & 351 (44 \%) & $191(43 \%)$ & 0.8 & $0.9[0.7-1.2]$ & $127(47 \%)$ & 0.5 & $1.0[0.8-1.4]$ & 64 (38 \%) & 0.2 & $0.7[0.5-1.1]$ \\
\hline $\mathrm{T} / \mathrm{T}$ & $114(14 \%)$ & 57 (13\%) & 0.5 & $0.8[0.6-1.2]$ & 29 (11 \%) & 0.3 & $0.7[0.4-1.2]$ & $28(16 \%)$ & 0.8 & $1.0[0.6-1.7]$ \\
\hline $\mathrm{C} / \mathrm{T}+\mathrm{T} / \mathrm{T}$ & 465 (58 \%) & 248 (56 \%) & 0.6 & $0.9[0.7-1.2]$ & 156 (58 \%) & 0.9 & $1.0[0.7-1.3]$ & 92 (54 \%) & 0.3 & $0.8[0.6-1.1]$ \\
\hline Allele C & $1035(0.64)$ & $575(0.65)$ & - & 1.0 (ref) & $353(0.66)$ & - & 1.0 (ref) & $234(0.66)$ & - & 1.0 (ref) \\
\hline Allele T & $579(0.36)$ & $305(0.35)$ & 0.5 & $0.9[0.8-1.1]$ & $185(0.34)$ & 0.5 & $0.9[0.7-1.1]$ & $120(0.34)$ & 0.5 & $0.9[0.7-1.1]$ \\
\hline \multicolumn{11}{|c|}{ rs6505162 (Pre-miR 423) } \\
\hline$C / C$ & 284 (35\%) & $125(28 \%)$ & - & 1.0 (ref) & 74 (28 \%) & - & 1.0 (ref) & $51(30 \%)$ & - & 1.0 (ref) \\
\hline$C / A$ & 385 (48 \%) & $229(52 \%)$ & 0.02 & $1.3[1.0-1.8]$ & 141 (52 \%) & 0.03 & $1.4[1.0-1.9]$ & 88 (51%) & 0.2 & $1.3[0.9-1.9]$ \\
\hline $\mathrm{A} / \mathrm{A}$ & $138(17 \%)$ & 86 (20 \%) & 0.05 & 1.4 [1.0-1.9] & 54 (20\%) & 0.05 & $1.5[1.0-2.3]$ & 32 (19 \%) & 0.3 & $1.3[0.8-2.1]$ \\
\hline$C / A+A / A$ & $523(65 \%)$ & 315 (72 \%) & 0.01 & $1.4[1.2-1.8]$ & 195 (72 \%) & 0.02 & $1.4[1.0-1.9]$ & 120 (70 \%) & 0.1 & $1.3[0.9-1.8]$ \\
\hline Allele C & $953(0.59)$ & $479(0.54)$ & - & 1.0 (ref) & $289(0.54)$ & - & 1.0 (ref) & $190(0.56)$ & - & 1.0 (ref) \\
\hline Allele A & $661(0.41)$ & $401(0.46)$ & 0.02 & $1.2[1.0-1.4]$ & $249(0.46)$ & 0.03 & $1.2[1.0-1.5]$ & $152(0.44)$ & 0.2 & $1.1[0.9-1.4]$ \\
\hline & & \multicolumn{3}{|c|}{ All BC cases $(n=440)$} & \multicolumn{3}{|c|}{$\begin{array}{l}\text { Families with } \geq 2 \text { BC and/or } \\
\text { OC cases }(n=269)\end{array}$} & \multicolumn{3}{|c|}{$\begin{array}{l}\text { Families with a single case, } \\
\text { diagnosed at } \leq 50 \text { years of } \\
\text { age }(n=171)\end{array}$} \\
\hline $\begin{array}{l}\text { Genotype or } \\
\text { allele }\end{array}$ & $\begin{array}{l}\text { Controls (\%) } \\
(n=807)\end{array}$ & BC cases (\%) & $p$-value ${ }^{a}$ & OR $[95 \% \mathrm{Cl}]$ & BC cases (\%) & $p$-value ${ }^{a}$ & OR $[95 \% \mathrm{Cl}]$ & BC cases (\%) & $p$-value ${ }^{a}$ & OR $[95 \% \mathrm{Cl}]$ \\
\hline \multicolumn{11}{|c|}{ rs4919510 (miR 608) } \\
\hline $\mathrm{C} / \mathrm{C}$ & 431 (53.4 \%) & 226 (51 \%) & - & 1.0 (ref) & $141(52 \%)$ & - & 1.0 (ref) & $85(50 \%)$ & - & 1.0 (ref) \\
\hline$C / G$ & 310 (38.4 \%) & $174(40 \%)$ & 0.6 & $1.0[0.8-1.4]$ & $104(39 \%)$ & 0.8 & $1.0[0.7-1.3]$ & 70 (41\%) & 0.4 & $1.1[0.8-1.6]$ \\
\hline $\mathrm{G} / \mathrm{G}$ & $66(8.2 \%)$ & 40 (9 \%) & 0.5 & $1.1[0.7-1.7]$ & 24 (9 \%) & 0.6 & $1.1[0.6-1.8]$ & 16 (9 \%) & 0.5 & $1.2[0.6-2.2]$ \\
\hline $\mathrm{G} / \mathrm{G}+\mathrm{C} / \mathrm{G}$ & $376(46.6 \%)$ & 214 (49 \%) & 0.5 & $1.0[0.8-1.3]$ & $128(48 \%)$ & 0.7 & $1.0[0.7-1.3]$ & 86 (50 \%) & 0.4 & $1.1[0.8-1.6]$ \\
\hline Allele C & $1172(0.73)$ & $626(0.71)$ & - & 1.0 (ref) & $386(0.72)$ & - & 1.0 (ref) & $240(0.70)$ & - & 1.0 (ref) \\
\hline Allele G & $442(0.27)$ & $254(0.29)$ & 0.4 & $1.0[0.9-1.3]$ & $152(0.28)$ & 0.7 & $1.0[0.8-1.3]$ & $102(0.30)$ & 0.3 & $1.1[0.8-1.4]$ \\
\hline \multicolumn{11}{|c|}{ rs2682818 (Pre-miR 618) } \\
\hline$C / C$ & 699 (86.6 \%) & 359 (81.6 \%) & - & 1.0 (ref) & $221(82 \%)$ & - & 1.0 (ref) & 139 (81 \%) & - & 1.0 (ref) \\
\hline$C / A$ & $102(12.6 \%)$ & 78 (17.7 \%) & 0.01 & $1.4[1.0-2.0]$ & 45 (17 \%) & 0.1 & $1.4[0.9-2.1]$ & 32 (19 \%) & 0.04 & $1.6[1.0-2.4]$ \\
\hline $\mathrm{A} / \mathrm{A}$ & $6(0.7 \%)$ & $3(0.7 \%)$ & 1.0 & $0.9[0.2-3.9]$ & $3(1 \%)$ & 0.4 & $1.5[0.3-6.3]$ & 0 (0 \%) & 0.5 & $0.3[0.02-6.8]$ \\
\hline$C / A+A / A$ & 108 (13.3 \%) & 81 (18.4 \%) & 0.02 & $1.4[1.0-2.0]$ & 48 (18 \%) & 0.08 & $1.4[0.8-2.0]$ & 32 (19 \%) & 0.07 & $1.4[0.9-2.3]$ \\
\hline Allele C & $1500(0.93)$ & $796(0.90)$ & - & 1.0 (ref) & $487(0.91)$ & - & 1.0 (ref) & $310(0.91)$ & - & 1.0 (ref) \\
\hline Allele A & $114(0.07)$ & $84(0.10)$ & 0.03 & $1.3[1.0-1.8]$ & $51(0.09)$ & 0.08 & $1.3[0.9-1.9]$ & $32(0.09)$ & 0.1 & $1.3[0.9-2.0]$ \\
\hline
\end{tabular}

$B C$ breast cancer, $O C$ ovarian cancer, $O R$ odds ratio, $\mathrm{Cl}$ confidence interval 
In the single locus analyses, no significant differences were observed in the genotype and allele distributions for rs11614913:C $>\mathrm{T}$ or rs4919510:C $>\mathrm{G}$, either in the whole data set or in subgroups A or B $(p>0.05)$. With respect to rs6505162:C $>A$, the genotype and allele distribution was significantly different in the whole sample of $B R C A 1 / 2$-negative cases and in subgroup A, with respect to the controls $(p \leq 0.05)$. The minor allele frequency (MAF) (allele A) was higher in subgroup A cases than in controls (0.46 and 0.41 , respectively, $p=0.03$ ). Furthermore, in subgroup A, allele A carriers $(\mathrm{C} / \mathrm{A}+\mathrm{A} /$ A) had a significantly increased BC risk (OR $=1.4$ [ $95 \%$ CI $1.0-1.9] p=0.02$ ) (Table 2). We also analyzed the relationship between rs6505162 and BC risk within cases with a history familial $\mathrm{BC}$ according to number of $\mathrm{BC}$ cases in the family (Table 3). No association between rs6505162 and $\mathrm{BC}$ risk was found in cases belonging to families with two $\mathrm{BC}$ and/or OC cases. However, $\mathrm{BC}$ risk was significantly higher in cases with three or more family members affected by $\mathrm{BC}$ and/or OC. In these families, the allele A frequency was 0.48 in $\mathrm{BC}$ cases versus 0.41 in controls $(\mathrm{OR}=1.3$ [95 \% CI $1.0-1.7] p=0.04)$, and homozygous A/A were had a significantly increased $\mathrm{BC}$ risk $(\mathrm{OR}=1.7$ [95 \% CI $1.0-2.0] p=0.05)$. No association was found between rs6505162 and non-familial early-onset BC ( $\leq 50$ years) (Table 2). For rs2682818, located in pre-mir-618, in the whole sample, the MAF (allele A) was higher in cases (0.1) than controls (0.07), and the difference was statistically significant $(\mathrm{OR}=1.3$ [95\% CI 1.0-1.8] $p=0.03$ ). This result indicates that allele $\mathrm{A}$ is associated with increased $\mathrm{BC}$ risk. We also observed increased $\mathrm{BC}$ risk for allele A carriers $(\mathrm{C} / \mathrm{A}+$ $\mathrm{A} / \mathrm{A})$ in the whole sample $(\mathrm{OR}=1.4$ [95 \% CI $1.0-2.0$ ] $p=0.02$ ) (Table 2). When we analyzed the effect of allele A by number of $\mathrm{BC}$ cases per family, no association between rs2682818 and BC risk was found. Nevertheless, $\mathrm{BC}$ risk increased 1.6-fold in the heterozygous group (OR $=1.6$ [95 \% CI 1.0 - 2.4] $p=0.04)$ with non-familial early-onset $\mathrm{BC}$ ( $\leq 50$ years) (Table 3$)$.

The results for rs895819 showed that the homozygous genotype G/G was marginally associated with a protective effect in the whole sample $(\mathrm{OR}=0.6$ [CI $0.4-1.0] p=$ 0.08). Nevertheless, in the families with $2 \mathrm{BC}$ and/or OC cases, we observed decreased $\mathrm{BC}$ risk associated with

Table 3 Genotype and allele frequencies of rs895819, rs11614913, rs6505162, rs4919510, and rs2682818 by number of BC cases per family, in BRCA1/2-negative breast cancer cases and controls

\begin{tabular}{|c|c|c|c|c|c|c|c|}
\hline \multirow[b]{2}{*}{ Genotype or allele } & \multirow[b]{2}{*}{ Controls $(\%)(n=807)$} & \multicolumn{3}{|c|}{ Families with 2 BC and/or OC cases $(n=148)$} & \multicolumn{3}{|c|}{ Families with $\geq 3$ BC and/or OC cases $(n=121)$} \\
\hline & & BC cases $(\%)$ & $p$-value ${ }^{a}$ & OR $[95 \% \mathrm{Cl}]$ & BC cases $(\%)$ & $p$-value ${ }^{a}$ & OR $[95 \% \mathrm{Cl}]$ \\
\hline \multicolumn{8}{|c|}{ rs895819 (Pre-miR 27a) } \\
\hline A/A & $432(53 \%)$ & $83(56 \%)$ & - & 1.0 (Ref) & $63(52 \%)$ & - & 1.0 (Ref) \\
\hline$A / G$ & $298(37 \%)$ & $60(41 \%)$ & 0.8 & $1.0[0.7-1.5]$ & $45(37 \%)$ & 0.9 & $1.0[0.6-1.5]$ \\
\hline $\mathrm{G} / \mathrm{G}$ & $77(10 \%)$ & $5(3 \%)$ & 0.01 & $0.3[0.1-0.8]$ & $13(11 \%)$ & 0.6 & $1.1[0.6-2.2]$ \\
\hline$A / G+G / G$ & $375(47 \%)$ & $65(44 \%)$ & 0.5 & $0.9[0.6-1.2]$ & $58(48 \%)$ & 0.7 & $1.0[0.7-1.5]$ \\
\hline Allele A & $1162(0.72)$ & $226(0.76)$ & - & 1.0 (Ref) & $171(0.71)$ & - & 1.0 (Ref) \\
\hline Allele G & $452(0.28)$ & $70(0.24)$ & 0.1 & $0.7[0.5-1.0]$ & $71(0.29)$ & 0.7 & $1.0[0.7-1.4]$ \\
\hline \multicolumn{8}{|c|}{ rs6505162 (Pre-miR 423) } \\
\hline $\mathrm{C} / \mathrm{C}$ & $284(35 \%)$ & $41(28 \%)$ & - & 1.0 (Ref) & $33(27 \%)$ & - & 1.0 (Ref) \\
\hline $\mathrm{C} / \mathrm{A}$ & $385(48 \%)$ & $81(55 \%)$ & 0.07 & $1.4[0.9-2.2]$ & $60(50 \%)$ & 0.2 & $1.3[0.8-2.1]$ \\
\hline $\mathrm{A} / \mathrm{A}$ & $138(17 \%)$ & $26(17 \%)$ & 0.3 & $1.3[0.8-2.2]$ & $28(23 \%)$ & 0.05 & $1.7[1.0-2.0]$ \\
\hline$C / A+A / A$ & $523(65 \%)$ & $107(72 \%)$ & 0.08 & $1.4[1.0-2.1]$ & $88(73 \%)$ & 0.09 & $1.4[0.9-2.2]$ \\
\hline Allele C & $953(0.59)$ & $163(055)$ & - & 1.0 (Ref) & $126(0.52)$ & - & 1.0 (Ref) \\
\hline Allele A & $661(0.41)$ & $133(0.45)$ & 0.2 & $1.2[0.9-1.5]$ & $116(0.48)$ & 0.04 & $1.3[1.0-1.7]$ \\
\hline \multicolumn{8}{|c|}{ rs2682818 (Pre-miR 618) } \\
\hline $\mathrm{C} / \mathrm{C}$ & 699 (86.6 \%) & 120 (81%) & - & 1.0 (Ref) & 101 (83.5 \%) & - & 1.0 (Ref) \\
\hline$C / A$ & $102(12.6 \%)$ & $26(18 \%)$ & 0.1 & $1.3[0.9-2.3]$ & 19 (15.7\%) & 0.3 & $1.3[0.7-2.2]$ \\
\hline $\mathrm{A} / \mathrm{A}$ & $6(0.7 \%)$ & 2 (1 \%) & 0.3 & 1.9 [0.3-9.7] & 1 (0.8 \%) & 1.0 & 1.1 [0.1-9.6] \\
\hline$C / A+A / A$ & $108(13.3 \%)$ & $28(19 \%)$ & 0.09 & $1.5[1.0-2.5]$ & $20(16.5 \%)$ & 0.3 & $1.2[0.7-2.1]$ \\
\hline Allele C & $1500(0.93)$ & $266(0.90)$ & - & 1.0 (Ref) & $221(0.91)$ & - & 1.0 (Ref) \\
\hline Allele A & $114(0.07)$ & $30(0.10)$ & 0.07 & $1.4[0.9-2.2]$ & $21(0.09)$ & 0.3 & $1.2[0.7-2.0]$ \\
\hline
\end{tabular}

$B C$ breast cancer, $O C$ ovarian cancer, $O R$ odds ratio, $\mathrm{Cl}$ confidence interval ${ }^{\text {a}}$ Fisher's exact test

Bold values are statistically significant $(p<0.05)$ 
homozygous minor allele genotype (G/G genotype, $\mathrm{OR}=$ $0.3[95 \%$ CI $0.1-0.8] p=0.01$ ). This result indicates that the G/G genotype is associated with a protective effect in families with a moderate history of $\mathrm{BC}$.

\section{Discussion}

Mutations in BRCA1 and BRCA2 are associated with susceptibility to breast and ovarian cancer. At present, however, those mutations account for only a portion of familial cases, and consequently there is an intensive search for additional targets.

MiRNAs are a class of endogenous, non-coding, single-strand RNAs involved in many molecular pathways and biological processes including apoptosis, differentiation, proliferation, and immune response [55]. SNPs are the most common form of variation present in the human genome. SNPs in miRNA gene regions can affect miRNA function by modulating the transcription of the primary transcript, pri-miRNA and pre-miRNA processing, maturation, or miRNA-mRNA interaction, which could contribute to cancer susceptibility [56]. Recently, many epidemiological studies have examined the association of miRNA SNPs with $\mathrm{BC}$ susceptibility, but the results remain inconclusive. Genetic variability is ethnicity-specific, and to date the most miRNA SNP studies have been performed in cases from European, Asian, Arab, and Jewish populations, mainly with sporadic BC. With the exception of one study in a Brazilian population, the role of miRNA variation in BC susceptibility has not been analyzed in a Latin-American population. In the present study, we evaluated the impact of miRNA SNPs on familial and non-familial early-onset BC cases negative for point mutations in $B R C A 1 / 2$, from a Chilean population. To this end, we studied the association of BC risk with rs895819 in pre-miR27a, rs11614913 in pre-miR196a2, rs6505162 in pre-miR-423, rs4919510 in miR-608, and rs2682818 in pre-mir-618 in a case-control study.

Table 4 shows the results of association studies between SNPs: rs895819 (mir-27a), rs11614913 (miR196a2), rs6505162 (miR-423), rs4919510 (miR-608), rs2682818 (miR-618) and BC risk in others populations.

Our data do not support an association of rs11614913:C > $\mathrm{T}$ and rs4919510:C > G with breast cancer risk. With respect to rs11614913, several case-control studies have been conducted to investigate the association between this SNP with $\mathrm{BC}$ susceptibility, but the results have been contradictory. Specifically, case-control studies have shown that rs11614913 SNP is associated with increased BC risk in Han Chinese [29] and Saudi Arabian [57] populations. In contrast, results from studies performed in the United States [58] and China [59] showed that rs11614913 was associated with decreased BC susceptibility. Other studies in Italian, German, and Australian populations reported that

Table 4 Results of association studies of SNPs rs895819, rs11614913, rs6505162, rs4919510 and rs2682818 with BC risk in different populations

\begin{tabular}{|c|c|c|c|c|c|c|c|c|}
\hline \multirow[b]{2}{*}{ n. } & \multirow[b]{2}{*}{ MiRNA } & \multirow{2}{*}{$\begin{array}{l}\text { dbSNP } \\
\text { (variation) }\end{array}$} & \multirow[b]{2}{*}{ Phenotype } & \multirow[b]{2}{*}{ Author(s) } & \multicolumn{2}{|l|}{ Reference } & \multirow[b]{2}{*}{$N$ (cases) } & \multirow[b]{2}{*}{$\mathrm{N}$ (controls) } \\
\hline & & & & & Country & Ethnicity & & \\
\hline \multirow[t]{5}{*}{1} & miR-27a & rs895819 & Reduced familial BC & Yang R., et al. (2010) [20] & Germy & Caucasian & 1217 & 1422 \\
\hline & & & & Kontorovich T., et al. (2010) [26] & Israel & Jewish & 279 & 212 \\
\hline & & & & Catucci l., et al. (2012) [18] & Italy & Caucasian & 1025 & 1593 \\
\hline & & & & Zhang M.et al. (2012) [24] & China & Asian & 252 & 248 \\
\hline & & & & Wang B., et al. (2014) [16] & meta-analysis & & & \\
\hline \multirow[t]{9}{*}{2} & miR-196a2 & rs11614913 & Increased $\mathrm{BC}$ risk & Hu Z., et al. (2009) [23] & China & Asian & 1009 & 1093 \\
\hline & & & & Hoffman AE., et al. (2009) [51] & USA & Caucasian & 439 & 478 \\
\hline & & & & Catucci l., et al. (2010) [17] & Italy & Caucasian & 760 & 1243 \\
\hline & & & & Catucci l., et al. (2010) [17] & Germany & Caucasian & 1134 & 1517 \\
\hline & & & & Jedlinski DT., et al. (2011) [53] & Australia & Caucasian & 187 & 171 \\
\hline & & & & Alshatwi A., et al. (2012) [25] & Saudi Arabia & Arabian & 100 & 100 \\
\hline & & & & Zhang M.et al. (2012) [24] & China & Asian & 252 & 248 \\
\hline & & & & Linhares JJ., et al. (2012) [27] & Brazil & Brazilian & 388 & 388 \\
\hline & & & & Srivastava K., et al. (2012) [50] & meta-analysis & & 3449 & 4140 \\
\hline \multirow[t]{2}{*}{3} & miR-423 & rs6505162 & Increased $\mathrm{BC}$ risk & Kontorovich T., et al. (2010) [26] & Israel & Jewish & 279 & 212 \\
\hline & & & & Smith R., et al. (2012) [57] & Australia & Caucasian & 179 & 174 \\
\hline 4 & miR-608 & rs4919510 & Increased HERB2 + BC risk & Huang A-J.et al. (2012) [42] & China & Asian & 252 & 248 \\
\hline 5 & miR-618 & rs2682818 & Increased BC risk & Zhang M.et al. (2012) [24] & China & Asian & 252 & 248 \\
\hline
\end{tabular}


the common SNP rs11614913 was not associated with increased $\mathrm{BC}$ risk $[23,60]$. In Brazilian women with $\mathrm{BC}$, the $\mathrm{C} / \mathrm{C}$ genotype was associated with decreased $\mathrm{BC}$ risk, and the presence of the $\mathrm{T}$ allele was significantly associated with increased BC risk [33]. These discrepancies might be explained by different genetic backgrounds. The contemporary Chilean population stems from the admixture of Amerindian peoples with the Spanish settlers in the sixteenth and seventeenth centuries. Later (nineteenth century) migrations of Germans, Italians, Arabs, and Croatians have had only a minor impact on the overall population (not more than $4 \%$ of the total population) and are restricted to the specific locations of the country where they settled [61]. The relationship between ethnicity, Amerindian admixture, genetic markers, and socioeconomic strata has been extensively studied in Chile $[62,63]$. Thus, it is probable that in the mixed Chilean population, rs11614913 is not a significant contributor to $\mathrm{BC}$, similar to the results described for Caucasian populations. Another SNP found to have no association with BC risk in our study, rs4919510:C > G, is located in mature miR608. This is important because few polymorphisms are located in the mature microRNA sequence. Moreover, predicted targets of miR-608 include interleukin1 alpha (IL-1A), growth hormone receptor (GHR), and TP53 [44], all of which have reported associations with BC. The only case-control study, performed by Huang et al. [48] in Han Chinese women, reported that variant genotypes $(\mathrm{C} / \mathrm{G}+\mathrm{G} / \mathrm{G})$ were specifically associated with increased risk for the HER2-positive subtype in the recessive model, but not for other subtypes. In the Chilean population, we observed no association between this SNP and BC in the whole data set, the familial BC group (subgroup A), or the nonfamilial early-onset BC group (subgroup B). Nevertheless, our results are not comparable with those obtained in the Han Chinese women as our study did not consider pathologic features of the BC. Further studies in different ethnic groups are needed before concluding whether rs4919510:C > G alters BC susceptibility.

Several studies have evaluated the association between the SNP rs6505162 in pre-miR-423 and cancer risk in diverse populations and in different cancers, with contradictory outcomes. Nevertheless, there have been scarce association studies on this SNP and BC or OC risk. Kontorovich et al. [32] indicated that rs6505162 was associated with a significantly increased risk of ovarian cancer; on the contrary, Smith [64] showed that it conferred a reduced risk of $\mathrm{BC}$. A meta-analysis published by Chen et al. [22] reported no associations between the rs6505162 SNP and BC risk in any genetic model. However, this meta-analysis included only two association studies involving rs6505162 SNP, which is an important limitation to interpreting the results. In our study, we found that the
SNP rs6505162:C > A was significantly associated with increased risk of familial $\mathrm{BC}$ in the group with a strong family history of $\mathrm{BC}$. In these families, the homozygous genotype $\mathrm{A} / \mathrm{A}$ was associated with increased $\mathrm{BC}$ risk (OR $=1.7[95 \% \mathrm{CI} 1.0-2.0] p=0.05$ ). Our results are in accordance with the recent results obtained by Zhao et al. [43], who demonstrated that the SNP rs6505162 in premiR-423 affects mature miRNA expression and that miR423 plays a potentially oncogenic role in breast cancer tumorigenesis.

miR-618 deregulation has been related to a number of malignancies, such as hepatocellular carcinoma, [49], male breast cancer [50], and Barrett's esophageal cancer [51], suggesting a potential rol of this miRNA as a possible cancer biomarker. Because SNP rs2682818 is part of the miR618 precursor's stem-loop sequence, it can affect miR-618 levels. The SNP may alter the secondary stem-loop structure, which in turn influences how pre-miR-618 is processed into its mature form [52]. Recently, Fu et al. [52] reported that rs2682818:C > A may play a role in susceptibility to follicular lymphoma (OR $=1.65$ [95 \% CI 1.052.50]).; an in vitro analysis indicated that the variant A allele of rs2682818 lowered mature miR-618 levels. This reduction could trigger a deregulation of miR-618-controlled pathways associated with follicular lymphoma. With respect to $\mathrm{BC}$, the only case-control study published to date reported no association between rs 2682818 and BC risk in a Chinese population [30]. Our results showed that the rs2682818 C/A genotype is associated with an increased $\mathrm{BC}$ risk both in the whole sample and in the group with non-familial early-onset $\mathrm{BC}$. Our results are the first to contribute to identification of rs6505162 in pre-miR-423 and rs2682818 in pre-miR-618 as polymorphisms associated with increased $\mathrm{BC}$ risk in a South American population.

Six studies, including three meta-analyses, have examined the association between the rs895819 polymorphism in miR-27a and BC risk. The studies were conducted in German cases with familial BC, in Italian cases with familial BC, and in Chinese cases with sporadic BC. In the German familial BC cases, the rare (G) allele was shown to have a protective effect limited to cases with age at diagnosis $<50$ years $(\mathrm{OR}=0.83$ [95\% CI $0.70-0.98$ ] $p=0.0314)$ and bilateral $\mathrm{BC}(\mathrm{OR}=0.70$ [95\% CI $0.52-0.95] p=$ 0.0238). The results obtained by Catucci et al. [24] in Italian familial BC failed to support the association of rs895819 with BC risk. In a Chinese population, Zhang et al. [38] showed that in sporadic BC, only younger ( $<48$ years old) allele $\mathrm{G}(\mathrm{A} / \mathrm{G}+\mathrm{G} / \mathrm{G})$ carriers showed a significantly reduced $\mathrm{BC}$ risk $(\mathrm{OR}=0.535$ [95\% CI 0.321 0.891] $p=0.016)$. With respect to the meta-analyses, the first, which included 4 studies, concluded that subjects carrying the rs895819 $\mathrm{G}$ allele showed reduced $\mathrm{BC}$ risk [65]. The meta-analysis published by Bai et al. [66] found a 
significant association between rs895819 allele $\mathrm{G}$ and reduced $\mathrm{BC}$ risk in Caucasians, but not in Asians. A protective effect of rs895819 allele $\mathrm{G}$ was seen in the younger BC cases and in the subgroup of unilateral $\mathrm{BC}$ cases. In addition, the meta-analysis published by Chen et al. [22] reported that the miR-27a rs895819 G allele might be a protective factor for $\mathrm{BC}$ among Caucasians. Our results in a Chilean mixed population showed that the MAF (allele G) in the controls was low (0.28), similar to the East Asian population [67]. In the whole sample, we observed a marginally protective effect of the genotype G/G, which was likely attributable to SNP frequency and sample sizes. Nevertheless, in the subgroup A, which included families with a moderate $B C$ history, the $\mathrm{G} / \mathrm{G}$ genotype is significantly associated with reduced $\mathrm{BC}$ risk. These results are consistent with the meta-analysis which reported reduced $\mathrm{BC}$ risk in Caucasians, as the Chilean population is $60 \%$ Caucasian [68].

\section{Conclusions}

The contribution of miRNA-gene variants to BC susceptibility in South-American women had been unexplored, with the exception of one study in a Brazilian population. Our findings support the following conclusions: a) rs6505162:C > A in pre-miR-423 increases risk of familial $\mathrm{BC}$ in families with a strong history of $\mathrm{BC}$; b) the $\mathrm{C} / \mathrm{A}$ genotype at rs2682818:C > A (pre-miR-618) increases BC risk in non-familial early-onset $\mathrm{BC}$; and c) the $\mathrm{G} / \mathrm{G}$ genotype at rs895819:A > G (miR-27a) reduces $\mathrm{BC}$ risk in families with a moderate history of BC.

\section{Abbreviations}

miRNA, microRNA; SNP, Single Nucleotide Polymorphism; BR, breast cancer; $\mathrm{OC}$, ovarian cancer; $\mathrm{OD}$, odds ratio; $\mathrm{Cl}$, confidence interval

\section{Acknowledgements \\ The authors thank the many families who participated in the research studies described in this article. We acknowledge the CONCAC Breast Cancer Group: Maria Teresa Barrios, Angelica Soto, Rossana Recabarren, Leticia Garcia, Karen Olmos, and Paola Carrasco. Grant Sponsor: Fondo Nacional de Desarrollo Científico y Tecnológico (FONDECYT), grant number 1150117.}

\section{Availability of data and materials}

All genotypes and frequencies for the studied SNPs in this population were deposited in dbSNP. The data will be publicly available within this year (2016) due an update in the platform.

\section{Authors' contributions}

$\sqcup J$ conceived of the study and participated in its design and coordination; SM and FG carried out the Genotyping assays; SM performed the statistical analysis; LJ, RFR, and SM prepared the manuscript; PGH participated in the design of the study and performed the statistical analysis; JMR, TB, FGO and EW selected familial breast cancer cases from the various oncology services; TB was responsible for selecting control. All authors read and approved the final manuscript

\section{Competing of interests}

The authors declare that they have no competing interests.

Consent for publication

Not applicable.

\section{Ethics approval and consent to participate}

This research was performed in accordance with the Helsinki Declaration and was approved by the ethics committee of University of Chile/School of Medicine (Ethics Committee of Research in Humans). Informed consent for this research was conducted under the approval of the ethics committee of the University of Chile/School of Medicine.

\section{Open access}

This article is distributed under the terms of the Creative Commons Attribution 4.0 International License (http://creativecommons.org/licenses/by/ 4.0/), which permits unrestricted use, distribution, and reproduction in any medium, provided you give appropriate credit to the original author(s) and the source, provide a link to the Creative Commons license, and indicate if changes were made. The Creative Commons Public Domain Dedication waiver (http://creativecommons.org/publicdomain/zero/1.0/) applies to the data made available in this article, unless otherwise stated.

\section{Author details}

${ }^{1}$ Human Genetics Program, Institute of Biomedical Sciences (ICBM), School of Medicine, University of Chile, Av. Independencia 1027, Santiago, Chile.

${ }^{2}$ Universidad Andres Bello, Facultad de Ciencias Biológicas, República №217, Santiago, Chile. ${ }^{3}$ Hospital Clínico San Borja Arriaran, Avenida Santa Rosa 1234, Santiago, Chile. ${ }^{4}$ Pathology and Oral Medicine, School of Odontology, University of Chile, Sergio Livingstone Pohlhammer 943, Santiago, Chile. ${ }^{5}$ National Cancer Society Corporación Nacional del Cáncer CONAC, Santiago, Chile. ${ }^{6}$ Clínca Las Condes, Santiago, Chile. ${ }^{7}$ Clínica Santa María, Santiago, Chile. ${ }^{8}$ Laboratorio de Genética Molecular Humana, Facultad de Medicina, Instituto de Ciencias Biomédicas (ICBM), Programa de Genética, Universidad de Chile, Independencia 1027, Santiago, Chile.

Received: 13 March 2016 Accepted: 8 July 2016

Published online: 15 July 2016

\section{References}

1. Chile Gd: Guía Clínica: Cáncer de Mama In. Edited by Salud Md. Santiago, Chile: Ministerio de Salud (MINSAL); 2011: 7-8.

2. Anglian Breast Cancer Study Group. Prevalence and penetrance of BRCA1 and BRCA2 mutations in a population-based series of breast cancer cases. Anglian Breast Cancer Study Group. Br J Cancer 2000, 83(10):1301-1308.

3. Leyton $Y$, Gonzalez-Hormazabal P, Blanco R, Bravo T, Fernandez-Ramires $R$, Morales S, Landeros N, Reyes JM, Peralta O, Tapia JC, et al. Association of PALB2 sequence variants with the risk of familial and early-onset breast cancer in a South-American population. BMC Cancer. 2015;15:30.

4. Gonzalez-Hormazabal P, Reyes JM, Blanco R, Bravo T, Carrera I, Peralta O, Gomez F, Waugh E, Margarit S, Ibanez G, et al. The BARD1 Cys557Ser variant and risk of familial breast cancer in a South-American population. Mol Biol Rep. 2012;39(8):8091-8

5. Gonzalez-Hormazabal P, Bravo T, Blanco R, Valenzuela CY, Gomez F, Waugh E, Peralta O, Ortuzar W, Reyes JM, Jara L. Association of common ATM variants with familial breast cancer in a South American population. BMC Cancer. 2008:8:117.

6. Gonzalez-Hormazabal P, Castro VG, Blanco R, Gomez F, Peralta O, Waugh E, Bravo T, Reyes JM, Jara L. Absence of CHEK2 1100delC mutation in familial breast cancer cases from a South American population. Breast Cancer ResTreat. 2008:110(3):543-5.

7. Jara L, Acevedo ML, Blanco R, Castro VG, Bravo T, Gomez F, Waugh E, Peralta O, Cabrera E, Reyes JM, et al. RAD51 135G > C polymorphism and risk of familial breast cancer in a South American population. Cancer Genet Cytogenet. 2007;178(1):65-9.

8. Jara L, Gonzalez-Hormazabal P, Cerceno K, Di Capua GA, Reyes JM, Blanco R, Bravo T, Peralta O, Gomez F, Waugh E, et al. Genetic variants in FGFR2 and MAP3K1 are associated with the risk of familial and early-onset breast cancer in a South-American population. Breast Cancer Res Treat. 2013;137(2):559-69.

9. Elematore I, Gonzalez-Hormazabal P, Reyes JM, Blanco R, Bravo T, Peralta O, Gomez F, Waugh E, Margarit S, Ibanez G, et al. Association of genetic variants at TOX3, 2q35 and 8q24 with the risk of familial and early-onset breast cancer in a South-American population. Mol Biol Rep. 2014;41(6):3715-22.

10. Stratton MR, Rahman N. The emerging landscape of breast cancer susceptibility. Nat Genet. 2008;40(1):17-22. 
11. Wightman B, Ha I, Ruvkun G. Posttranscriptional regulation of the heterochronic gene lin-14 by lin-4 mediates temporal pattern formation in C. elegans. Cell. 1993;75(5):855-62.

12. Lee $R C$, Feinbaum $R L$, Ambros $V$. The $C$. elegans heterochronic gene lin-4 encodes small RNAs with antisense complementarity to lin-14. Cell. 1993; 75(5):843-54.

13. He L, Hannon GJ. MicroRNAs: small RNAs with a big role in gene regulation. Nat Rev Genet. 2004:5(7):522-31.

14. Lewis BP, Burge CB, Bartel DP. Conserved seed pairing, often flanked by adenosines, indicates that thousands of human genes are microRNA targets. Cell. 2005;120(1):15-20.

15. Erson AE, Petty EM. MicroRNAs in development and disease. Clin Genet. 2008;74(4):296-306.

16. Cheng AM, Byrom MW, Shelton J, Ford LP. Antisense inhibition of human miRNAs and indications for an involvement of miRNA in cell growth and apoptosis. Nucleic Acids Res. 2005;33(4):1290-7.

17. Xu P, Guo M, Hay BA. MicroRNAs and the regulation of cell death. Trends Genet. 2004;20(12):617-24.

18. Zhang B, Pan X, Cobb GP, Anderson TA. microRNAs as oncogenes and tumor suppressors. Dev Biol. 2007;302(1):1-12.

19. O'Day E, Lal A. MicroRNAs and their target gene networks in breast cancer Breast Cancer Res. 2010;12(2):201.

20. Lu J, Getz G, Miska EA, Alvarez-Saavedra E, Lamb J, Peck D, Sweet-Cordero A, Ebert BL, Mak RH, Ferrando AA, et al. MicroRNA expression profiles classify human cancers. Nature. 2005;435(7043):834-8.

21. Esquela-Kerscher A, Slack FJ. Oncomirs - microRNAs with a role in cancer. Nat Rev Cancer. 2006;6(4):259-69.

22. Chen $\mathrm{QH}$, Wang $\mathrm{QB}$, Zhang B. Ethnicity modifies the association between functional microRNA polymorphisms and breast cancer risk: a HuGE metaanalysis. Tumour Biol. 2014;35(1):529-43.

23. Catucci I, Yang R, Verderio P, Pizzamiglio S, Heesen L, Hemminki K, Sutter C, Wappenschmidt B, Dick M, Arnold N, et al. Evaluation of SNPs in miR-146a, miR196a2 and miR-499 as low-penetrance alleles in German and Italian familial breast cancer cases. Hum Mutat. 2010:31(1):E1052-7.

24. Catucci I, Verderio P, Pizzamiglio S, Bernard L, Dall'olio V, Sardella D, Ravagnani F, Galastri L, Barile M, Peissel B, et al. The SNP rs895819 in miR27 a is not associated with familial breast cancer risk in Italians. Breast Cancer Res Treat. 2012;133(2):805-7.

25. Pastrello C, Polesel J, Della Puppa L, Viel A, Maestro R. Association between hsa-mir-146a genotype and tumor age-of-onset in BRCA1/BRCA2-negative familial breast and ovarian cancer patients. Carcinogenesis. 2010;31(12): 2124-6.

26. Yang $R$, Schlehe $B$, Hemminki $K$, Sutter $C$, Bugert $P$, Wappenschmidt $B$, Volkmann J, Varon R, Weber BH, Niederacher D, et al. A genetic variant in the pre-miR-27a oncogene is associated with a reduced familial breast cancer risk. Breast Cancer Res Treat. 2010;121(3):693-702.

27. Garcia Al, Cox DG, Barjhoux L, Verny-Pierre C, Barnes D, Antoniou AC, Stoppa-Lyonnet D, Sinilnikova OM, Mazoyer S. The rs2910164:G > C SNP in the MIR146A gene is not associated with breast cancer risk in BRCA1 and BRCA2 mutation carriers. Hum Mutat. 2011;32(9):1004-7.

28. Lian H, Wang $L$, Zhang J. Increased risk of breast cancer associated with CC genotype of Has-miR-146a Rs2910164 polymorphism in Europeans. PLoS One. 2012;7(2):e31615.

29. Hu Z, Liang J, Wang Z, Tian T, Zhou X, Chen J, Miao R, Wang Y, Wang X, Shen $\mathrm{H}$. Common genetic variants in pre-microRNAs were associated with increased risk of breast cancer in Chinese women. Hum Mutat. 2009;30(1):79-84.

30. Zhang M, Jin M, Yu Y, Zhang S, Wu Y, Liu H, Chen B, Li Q, Ma X, Chen K. Associations of miRNA polymorphisms and female physiological characteristics with breast cancer risk in Chinese population. Eur J Cancer Care. 2012;21(2):274-80.

31. Alshatwi AA, Shafi G, Hasan TN, Syed NA, Al-Hazzani AA, Alsaif MA, Alsaif AA. Differential expression profile and genetic variants of microRNAs sequences in breast cancer patients. PLoS One. 2012;7(2):e30049.

32. Kontorovich T, Levy A, Korostishevsky M, Nir U, Friedman E. Single nucleotide polymorphisms in miRNA binding sites and miRNA genes as breast/ovarian cancer risk modifiers in Jewish high-risk women. Int J Cancer. 2010;127(3):589-97.

33. Linhares JJ, Azevedo Jr M, Siufi AA, de Carvalho CV, Wolgien Mdel C, Noronha EC, Bonetti TC, da Silva ID. Evaluation of single nucleotide polymorphisms in microRNAs (hsa-miR-196a2 rs11614913 C/T) from Brazilian women with breast cancer. BMC Med Genet. 2012;13:119.
34. Mertens-Talcott SU, Chintharlapalli S, Li X, Safe S. The oncogenic microRNA27a targets genes that regulate specificity protein transcription factors and the G2-M checkpoint in MDA-MB-231 breast cancer cells. Cancer Res. 2007; 67(22):11001-11.

35. Guttilla IK, White BA. Coordinate regulation of FOXO1 by miR-27a, miR-96, and miR-182 in breast cancer cells. J Biol Chem. 2009;284(35):23204-16.

36. Ma Y, Yu S, Zhao W, Lu Z, Chen J. miR-27a regulates the growth, colony formation and migration of pancreatic cancer cells by targeting Sprouty2. Cancer Lett. 2010;298(2):150-8

37. Sun Q, Gu H, Zeng Y, Xia Y, Wang Y, Jing Y, Yang L, Wang B. Hsa-mir-27a genetic variant contributes to gastric cancer susceptibility through affecting miR-27a and target gene expression. Cancer Sci. 2010;101(10):2241-7.

38. Zhang N, Huo Q, Wang X, Chen X, Long L, Jiang L, Ma T, Yang Q. A genetic variant in pre-miR-27a is associated with a reduced breast cancer risk in younger Chinese population. Gene. 2013:529(1):125-30.

39. Wang J, Wang Q, Liu H, Shao N, Tan B, Zhang G, Wang K, Jia Y, Ma W, Wang $\mathrm{N}$, et al. The association of miR-146a rs2910164 and miR-196a2 rs11614913 polymorphisms with cancer risk: a meta-analysis of 32 studies. Mutagenesis. 2012;27(6):779-88.

40. Lin J, Huang S, Wu S, Ding J, Zhao Y, Liang L, Tian Q, Zha R, Zhan R, He X. MicroRNA-423 promotes cell growth and regulates $\mathrm{G}(1) / \mathrm{S}$ transition by targeting p21Cip1/Waf1 in hepatocellular carcinoma. Carcinogenesis. 2011;32(11):1641-7.

41. Guan G, Zhang D, Zheng Y, Wen L, Yu D, Lu Y, Zhao Y. microRNA-423-3p promotes tumor progression via modulation of AdipoR2 in laryngeal carcinoma. Int J Clin Exp Patho. 2014;7(9):5683-91.

42. Liu J, Wang X, Yang X, Liu Y, Shi Y, Ren J, Guleng B. miRNA423-5p regulates cell proliferation and invasion by targeting trefoil factor 1 in gastric cancer cells. Cancer Lett. 2014;347(1):98-104.

43. Zhao H, Gao A, Zhang Z, Tian R, Luo A, Li M, Zhao D, Fu L, Dong JT, Zhu Z. Genetic analysis and preliminary function study of miR-423 in breast cancer Tumour Biol. 2015:36(6):4763-71.

44. Landi D, Gemignani F, Barale R, Landi S. A catalog of polymorphisms falling in microRNA-binding regions of cancer genes. DNA Cell Biol. 2008; 27(1):35-43.

45. Hefler LA, Grimm C, Lantzsch T, Lampe D, Leodolter S, Koelbl H, Heinze G, Reinthaller A, Tong-Cacsire D, Tempfer C, et al. Interleukin-1 and interleukin6 gene polymorphisms and the risk of breast cancer in caucasian women. Clin Cancer Res. 2005;11(16):5718-21.

46. Canzian F, Cox DG, Setiawan WW, Stram DO, Ziegler RG, Dossus L, Beckmann L, Blanche $H$, Barricarte A, Berg CD, et al. Comprehensive analysis of common genetic variation in 61 genes related to steroid hormone and insulin-like growth factor-I metabolism and breast cancer risk in the $\mathrm{NCl}$ breast and prostate cancer cohort consortium. Hum Mol Genet. 2010:19(19):3873-84.

47. Hu Z, Li X, Yuan R, Ring BZ, Su L. Three common TP53 polymorphisms in susceptibility to breast cancer, evidence from meta-analysis. Breast Cancer Res Treat. 2010;120(3):705-14.

48. Huang AJ, Yu KD, Li J, Fan L, Shao ZM. Polymorphism rs4919510:C > G in mature sequence of human microRNA-608 contributes to the risk of HER2-positive breast cancer but not other subtypes. PLoS One. 2012;7(5):e35252.

49. Abdalla MA, Haj-Ahmad Y. Promising Candidate Urinary MicroRNA Biomarkers for the Early Detection of Hepatocellular Carcinoma among High-Risk Hepatitis C Virus Egyptian Patients. J Cancer Educ. 2012;3:19-31.

50. Fassan M, Baffa R, Palazzo JP, Lloyd J, Crosariol M, Liu CG, Volinia S, Alder H, Rugge $\mathrm{M}$, Croce $\mathrm{CM}$, et al. MicroRNA expression profiling of male breast cancer. Breast Cancer Res. 2009;11(4):R58.

51. Fassan M, Volinia S, Palatini J, Pizzi M, Baffa R, De Bernard M, Battaglia G Parente $P$, Croce CM, Zaninotto $G$, et al. MicroRNA expression profiling in human Barrett's carcinogenesis. Int J Cancer. 2011;129(7):1661-70.

52. Fu A, Hoffman AE, Liu R, Jacobs Dl, Zheng T, Zhu Y. Targetome profiling and functional genetics implicate miR-618 in lymphomagenesis. Epigenetics. 2014;9(5):730-7.

53. Gonzalez-Hormazabal P, Gutierrez-Enriquez S, Gaete D, Reyes JM, Peralta O, Waugh E, Gomez F, Margarit S, Bravo T, Blanco R, et al. Spectrum of BRCA1/ 2 point mutations and genomic rearrangements in high-risk breast/ovarian cancer Chilean families. Breast Cancer Res Treat. 2011;126(3):705-16.

54. Chomczynski P. A reagent for the single-step simultaneous isolation of RNA, DNA and proteins from cell and tissue samples. BioTechniques. 1993; 15(3):532-4. 536-537. 
55. Ruan K, Fang X, Ouyang G. MicroRNAs: novel regulators in the hallmarks of human cancer. Cancer Lett. 2009;285(2):116-26.

56. Ryan BM, Robles Al, Harris CC. Genetic variation in microRNA networks: the implications for cancer research. Nat Rev Cancer.

2010;10(6):389-402.

57. Walsh T, King MC. Ten genes for inherited breast cancer. Cancer Cell. 2007; 11(2):103-5

58. Hoffman AE, Zheng T, Yi C, Leaderer D, Weidhaas J, Slack F, Zhang Y, Paranjape T, Zhu Y. microRNA miR-196a-2 and breast cancer: a genetic and epigenetic association study and functional analysis. Cancer Res. 2009; 69(14):5970-7.

59. Srivastava K, Srivastava A. Comprehensive review of genetic association studies and meta-analyses on miRNA polymorphisms and cancer risk. PLoS One. 2012;7(11):e50966.

60. Jedlinski DJ, Gabrovska PN, Weinstein SR, Smith RA, Griffiths LR. Single nucleotide polymorphism in hsa-mir-196a-2 and breast cancer risk: a case control study. Twin Res Hum Genet. 2011;14(5):417-21.

61. Cruz-Coke R. Ethnic origin and evolution of the Chilean population. Rev Med Chile. 1976;104(6):365-8.

62. Valenzuela CY, Harb Z. Socioeconomic assortative mating in Santiago, Chile: a demonstration using stochastic matrices of mother-child relationships applied to ABO blood groups. Soc Biol. 1977;24(3):225-33.

63. Valenzuela CY, Acuna MP, Harb Z. Sociogenetic gradient in the Chilean population. Rev Med Chile. 1987;115(4):295-9.

64. Smith RA, Jedlinski DJ, Gabrovska PN, Weinstein SR, Haupt L, Griffiths LR. A genetic variant located in miR-423 is associated with reduced breast cancer risk. Cancer Genom Proteom. 2012;9(3):115-8.

65. Xu Q, He CY, Liu JW, Yuan Y. Pre-miR-27a rs895819A/G polymorphisms in cancer: a meta-analysis. PLoS One. 2013;8(6):e65208.

66. Bai RP, Weng Y, Su LL, Jin MJ, Xu ZP, Lu LQ, Chen GD. Association of a premiR-27a polymorphism with cancer risk: an updated meta-analysis. Asian Pac J Cancer P. 2014;15(23):10107-14.

67. [http://www.1000genomes.org/] Accessed 10 May 2016.

68. Fuentes M, Pulgar I, Gallo C, Bortolini MC, Canizales-Quinteros S, Bedoya G, Gonzalez-Jose R, Ruiz-Linares A, Rothhammer F. Gene geography of Chile: regional distribution of American, European and African genetic contributions. Rev Med Chile. 2014;142(3):281-9.

\section{Submit your next manuscript to BioMed Central and we will help you at every step:}

- We accept pre-submission inquiries

- Our selector tool helps you to find the most relevant journal

- We provide round the clock customer support

- Convenient online submission

- Thorough peer review

- Inclusion in PubMed and all major indexing services

- Maximum visibility for your research

Submit your manuscript at www.biomedcentral.com/submit 